\title{
TOWARD POSITIONAL CLONING OF EVERBLOOMING GENE (EVB) IN PLANTS: A BAC LIBRARY OF ROSA CHINENSIS CV. OLD BLUSH
}

\author{
A Thesis \\ by \\ GREGORY HESS \\ Submitted to the Office of Graduate Studies of \\ Texas A\&M University \\ in partial fulfillment of the requirements for the degree of \\ MASTER OF SCIENCE
}

August 2005

Major Subject: Plant Breeding 
TOWARD POSITIONAL CLONING OF EVERBLOOMING GENE

(EVB) IN PLANTS: A BAC LIBRARY OF ROSA CHINENSIS CV. OLD

BLUSH

\author{
A Thesis \\ by \\ GREGORY HESS
}

\author{
Submitted to the Office of Graduate Studies of \\ Texas A\&M University \\ in partial fulfillment of the requirements for the degree of \\ MASTER OF SCIENCE
}

Approved by:

Chair of Committee, Hongbin Zhang

Committee Members, David Byrne

Dirk Hayes

Head of Department, $\quad$ C. Wayne Smith

August 2005

Major Subject: Plant Breeding 


\author{
ABSTRACT \\ Toward Positional Cloning of Everblooming Gene (evb) in Plants: A BAC Library of Rosa \\ chinensis cv. Old Blush. (August 2005) \\ Gregory Hess, B.S., University of Texas at Arlington \\ Chair of Advisory Committee: Dr. Hongbin Zhang
}

A majority of commercial rose varieties bloom repeatedly throughout the year, as compared to most rose species, other woody ornamentals, and fruit crops that bloom once a year. This recurrent flowering feature of the commercial roses resulted from a flowering mutation named everblooming $(e v b)$. The mutation is recessive to once blooming and is found in the rose species Rosa chinensis. Although several molecular maps have been developed for rose, little is known about the evb gene, except for its classic genetics. The purpose of this study was to develop a large-insert bacterial artificial chromosome (BAC) library as a starting tool for molecular cloning and analysis of the $e v b$ gene by map-based cloning. To construct the large-insert BAC library, nuclear megabase-size DNA was isolated from the recurrent blooming diploid species, Rosa chinensis cv. Old Blush. The DNA was then partially digested with BamHI and separated on agarose gels by multi-phase pulsed-field gel electrophoresis. Size selected fragments estimated between $100 \mathrm{~kb}$ and 150 $\mathrm{kb}$ in size were cloned into the $\mathrm{pECBAC} 1 \mathrm{BAC}$ vector and the clones having rose DNA inserts were arrayed in 80 384-well microplates individually, with each clone being barcoded. The library contains 30,720 clones, has an average insert size of $108 \mathrm{~kb}$ and covers roughly $5.9 x$ genome equivalents, with a $>99 \%$ probability of isolating a single-copy clone 
from the library. The library is now available to be screened with the genes cloned from other species that control vernalization and floral development and will be used in mapbased cloning of the evb gene using a Rosa wichuraiana ('Basye's Thornless') x 'Old Blush' backcross population. 


\section{ACKNOWLEDGEMENTS}

I would like to thank GOD through whom all things are possible.

I would like to also thank my academic advisor, Dr. Hongbin Zhang, for all his patience, guidance, and mentorship. He has generously shared his knowledge and lab with me. Additionally, I give gratitude to the Zhang lab for all their assistance and support, especially Dr. Mikyung Lee, Chantel Scheuring, Felipe Santos, Dr. Chengcang Wu, and Dr. Taesik Uhm.

Thanks to my other committee members, Dr. David Byrne who generously provided the stock plants and Dr. Dirk Hays. For assisting me with plant material and guidance in this project, I would like to thank Natalie Anderson and Millie Burrell from the Byrne lab and Dr. Joe Novak from the Department of Horticultureal Sciences.

Thank you, Dr. C. Wayne Smith, for the chance and thank you, Dr. Ping Zhang, for the continued encouragement. 


\section{TABLE OF CONTENTS}

Page

ABSTRACT

iii

ACKNOWLEDGEMENTS.....................................................................

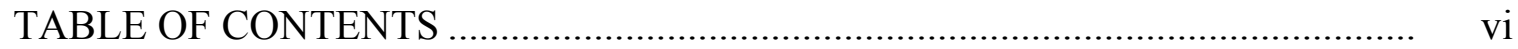

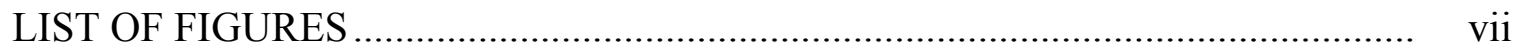

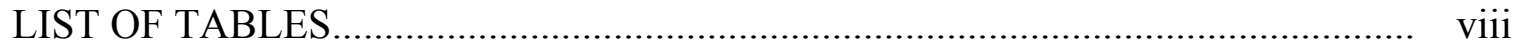

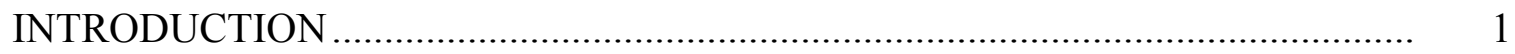

MATERIALS AND METHODS ................................................................... 5

Plant Materials and HMW DNA Isolation .................................................... 5

Embedding the Nuclei in Low-melting-point (LMP) Agarose Plugs

and Purification of Megabase DNA .......................................................... 6

Determination of Optimal Partial Digestion Conditions .............................. 7

Large-scale Partial Digestion of Megabase DNA, Size Selection,

Ligation and Transformation .......................................................................... 8

Transformation and Screening of Ligations .............................................. 9

BAC Insert Analysis by PFGE ............................................................... $\quad 10$

Library Assembly ............................................................................... 10

High-density Clone Filter Preparation for Library Screening ....................... 11

Primer Design ................................................................................. 11

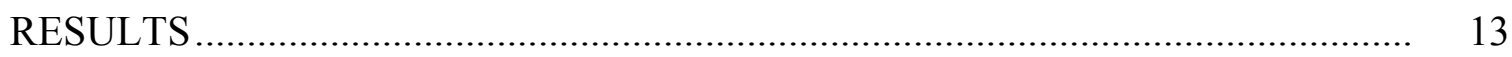

Improved HMW DNA Isolation from Roses ......................................... 13

BAC Library Construction ........................................................................ 16

Library Filter Preparation and Gene-specific Primer Design for Isolation of

the BAC Clones Containing Candidate Genes for Rose Everblooming (evb). 26

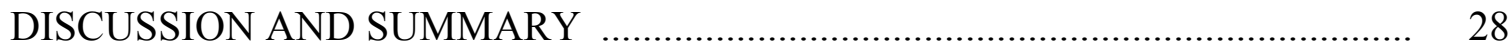

Procedure of Megabase-sized DNA Preparation for Rose ............................ 28

Large-insert BAC Library for Rose Everblooming Cultivar Old Blush ......... 29

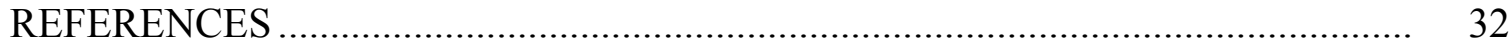

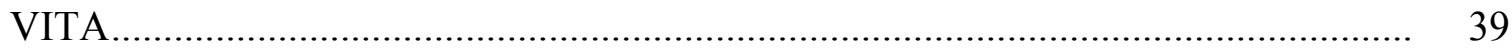




\section{LIST OF FIGURES}

FIGURE $\quad$ Page

$1 \quad$ Megabase-sized DNA isolated from rose...................................... 14

2 Rose DNA partially digested with BamHI and size-selected on a pulsed-field agarose gel ...................................................... 17

3 Size selection of BamHI-partially digested fragments on a pulsed-field gel for BAC library construction............................... 18

4 Quantification of DNA fragments resulted from size selection on a $1 \%$ agarose gel ...................................................................... 19

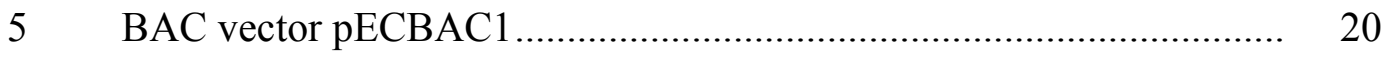

$6 \quad$ Rosa chinensis BACs digested with Not I and fractioned by PFGE ......................................................................... 24

$7 \quad$ Insert size distribution of the $R$. chinensis cv. Old Blush BAC library 


\section{LIST OF TABLES}

TABLE Page

1 Ligation of the three fractions of size-selected DNA fragments into the BamHI-digested, dephosphorylated pECBAC1 vector .....................................................................

2 Summary analysis of the clones resulting from three fractions of size-selected DNA fragments...................................... 22

3 Designed primers for isolation of homeologous and orthologous genes in rose using the rose $\mathrm{cv}$. Old Blush BAC library 


\section{INTRODUCTION}

Roses (Rosa species) are considered to be one of the most economically important ornamental crops. They are used for garden and cut flowers (Gudin 1998) and are harvested for extraction of their various compounds for perfume and medicinal uses. Roses have been cultivated as ornamental crops for thousands of years, yet only from the early 20th century have breeders used the knowledge of genetics in rose breeding and genetic improvement (DeVries and Duboise 1984,1996). There are between 170 and 300 species of roses with various ploidy levels, but only $8-10$ of them have been used in ornamental culture (Ma 2000; Rajapakse et al. 2001). Historically, the tetraploid or triploid hybrid roses have been cultivated for floral fragrance, quality, color, and blooming characteristics, whereas some wild species have been found recently to exhibit agriculturally relevant resistance to black spot and powdery mildew (Malek and Debener 1998; Linde and Debener 2003). In addition, other traits such as winter hardiness, male sterility, and absence of prickles have also been studied genetically (Semeniuk 1971; DeVries and Dubois 1978, 1984; Malek and Debener 1998; Debener 1999).

Roses have relatively small genomes. It has been estimated that the genome sizes of roses are between 380 and 670 megabases (Mb)/1C. (Yokoya et al. 2000; Rajapakse 2001). Being only 4 times the size of Arabidopsis, the relatively small genome size of rose facilitates the isolation of genes that are unique in the species through positional or mapbased cloning strategies. Nevertheless, it is currently not possible to clone the genes of

This thesis follows the style of Theoretical and Applied Genetics. 
interest in the species due to a shortage of essential resources and tools such as a largeinsert DNA library essential for the process of isolating genes known by phenotype for positional cloning.

In addition to their relatively small genome size, roses have many interesting and important traits that are unique or absent in the model plant species, such as Arabidopsis thaliana, rice, Medicago truncatula, and Prunus persica. One of the most significant is the gene controlling all season blooming (Semeniuk 1971; DeVries and Dubois 1984). This gene is designated as the recurrent flowering or ever-blooming (evb) gene. Recurrent flowering refers to a plant's ability to bloom repeatedly throughout the year. The rose evb gene is a unique single gene mutation discovered so far within the plant kingdom controlling recurrent flowering. More importantly, it has been shown to be conditioned by a recessive allele at a single locus (Semeniuk 1971; DeVris and Dubois 1978, 1984, 1996; Debner et al. 2001). Normally, seasonal blossoms begin after a 1 - 3 year plant juvenility or maturation stage has occurred. Vernalization provided by winter cold often is required for transition from vegetative growth to reproductive inflorescence (Taiz and Zeiger 1998) and is possibly mediated by epigenetic actions or alternatively splicing related genes (Koornneef et al. 1994; Lee et al. 1994; Chandler et al. 1996; Gendall et al. 2001). Instead of having a single bloom period in spring, the evb mutant confers recurrent flowering throughout the entire growing season (Semeniuk 1971; DeVries and Dubois 1984, 1996). Moreover, the mutant has also been found to significantly reduce the juvenility period to first bloom. Therefore, the mutant not only enables earlier reproduction of plants by a few years, but also ensures continued production, even after an unexpected spring frost that kills the first set of blooms. As advances in biotechnology have enabled more efficient gene 
transfer in many crop plants, the $e v b$ gene, once cloned, could be translated (Gould et al. 2002; Condliffe et al. 2003) into more precocious and extended harvest or bloom period in other woody ornamentals, small fruit, and fruit tree species.

Because there is no information on the sequence and biochemistry of the evb gene, the positional or map-based cloning approach has emerged as the method of choice to clone the gene. There are three major prerequisites to clone a gene of interest by positional cloning. One is the genetic mapping of the target gene to its locus in the genome using DNA markers. The second one is a large-insert DNA library that is required to approach the gene from its closely linked DNA marker(s) via chromosome walking. The third one is the availability of genetic transformation technique for gene identification through genetic complementation. The recent development of DNA markers (AFLPs, RFLPs and SSRs) and genetic maps in roses have allowed genetic mapping of various traits (Debener 1999; Rajapakse et al. 2001; Crespel et al. 2002). Additionally, agrobacterium-mediated transformation has demonstrated the ability to introduce genes of interest into the rose (Firoozabady et al. 1994; van der Salm et al. 1997). These tools, combined with the recent development of a Rosa wichuraiana ('Basye's Thornless') x 'Old Blush’ backcross population (WOB; unpublished), will allow mapped-based cloning of the evb gene and its subsequent introduction into once blooming trait plants. As such, the availability of a largeinsert DNA library for the rose line that harbors the $e v b$ gene is the limiting factor of isolating the gene.

Large-insert bacterial artificial chromosome (BAC) libraries have been proven in many crop plants to be desirable resources for genome research, including positional gene cloning and characterization. Maintaining a relatively large insert size and high stability 
while having low level of chimeric clones and ease of purifying cloned DNA makes the BAC system the prevailing choice for complex genome analysis (Zhang et al. 1996). Therefore, to facilitate positional cloning of the black spot resistance gene (Rdr1), one of the most serious fungal diseases in roses, Kaufmann et al. (2003) previously constructed a BAC library from a tetraploid clone of Rosa rugosa. Using this BAC library, they are working toward isolation of the Rdr1 gene by positional cloning (Kaufmann et al. 2003). This BAC library consists of 27,264 clones and has an average insert size of about $102 \mathrm{~kb}$, being equivalent to about $5.2 \mathrm{x}$ of the $R$. rugosa haploid genome. Because our long-term goal of this research is to isolate the evb gene by positional cloning, the objective of this study was to construct an essential large-insert BAC library from a rose line containing the target evb gene. 


\section{MATERIALS AND METHODS}

\section{Plant Materials and HMW DNA Isolation}

Green house-grown diploid $R$. chinensis cv. 'Old Blush' plants $(2 x=2 n=14)$ were pruned significantly to allow for new shoot development and then immediately fertilized with water soluble Technigro-Plus (20 N-18 P-18 K) by dissolving 1oz. into 1 gallon of water. After the new shoots appeared at about 5 days post fertilization, the rose plants were placed in the dark for 4 days to minimize the phenolic and other metabolic substances that potentially affect DNA quality. Between 20-50 grams of young leaf and shoot tissues were then harvested from the new growth and either frozen for storage at $-80^{\circ} \mathrm{C}$, or ground in liquid nitrogen to isolate nuclei according to Zhang et al.. (Zhang et al. 1995; Zhang 2000), with modifications by increasing the number of centrifugation washes interspersed with subsequent filtrations by clean Mira-cloth layered in new cheesecloth.

Homogenization of tissue was achieved by grinding approximately $50 \mathrm{~g}$ of frozen or fresh young leaf tissue into fine powder in liquid nitrogen with mortar and pestle, then immediately transferred into an ice cold beaker containing $1 \mathrm{~L}$ ice-cold $1 \mathrm{x}$ nuclei extraction buffer [ $0.5 \mathrm{M}$ sucrose, $10 \mathrm{mM}$ Trizma, $80 \mathrm{mM} \mathrm{KCl,} 10 \mathrm{mM}$ EDTA, $1 \mathrm{mM}$ spermidine (spd), $1 \mathrm{mM}$ spermine, $\mathrm{pH} 9.4-9.5,0.15 \%(\mathrm{v} / \mathrm{v}) \beta$-mercaptoethanol, $0.5 \%(\mathrm{v} / \mathrm{v})$ Triton $\mathrm{X}-$ 100]. The mixture was incubated on ice for $10 \mathrm{~min}$ with gentle stirring, and then filtered with one layer of Mira-cloth and two layers of cheesecloth into six ice-cold $250 \mathrm{ml}-$ centrifuge bottles. Since the homogenate was sticky, it was filtered with assistance by handy squeezing. The nuclei in the filtrate were pelleted by centrifugation in a fixed-angle rotor at $1,880 \mathrm{~g}$ at $4^{\circ} \mathrm{C}$ for $20 \mathrm{~min}$. After discarding the supernatant, re-suspension of the pellet was 
achieved by adding $1 \mathrm{ml}$ of the nuclei extraction buffer while assisting re-suspension by agitating with a small paintbrush; and then adding additional $30 \mathrm{ml}$ of the nuclei extraction buffer. The nuclei suspension was filtered again with two layers of Mira-cloth into a $50 \mathrm{ml}$ centrifuge tube and pelleted in a swinging bucket centrifuge at $1,920 \mathrm{~g}$ (note that $\mathrm{g}$ is not equal to rpm) at $4^{\circ} \mathrm{C}$ for $20 \mathrm{~min}$. In the same way, the resulting pellet was washed and filtered three more times. After the final wash, the nuclei were re-suspended in 1-5 $\mathrm{ml}$ of the nuclei extraction buffer without B-mercaptoethanol and Triton X-100, diluted to approximately $5 \times 10^{7}$ nuclei / $\mathrm{ml}$, and then stored on ice.

\section{Embedding the Nuclei in Low-melting-point (LMP) Agarose Plugs and Purification of Megabase DNA}

After obtaining a satisfactory quality and concentration of $R$. chinensis nuclei (Zhang et al. 1995), the nuclei were then pre-warmed at $45^{\circ} \mathrm{C}$ in a water bath for $5 \mathrm{~min}$, mixed with a same volume of melted $1 \%$ LMP agarose maintained in the $45^{\circ} \mathrm{C}$ water bath and aliquoted into 100-ul moldings on ice with a cut-off pipette tip. After completely solidifying, the agarose plugs containing rose nuclei were transferred into 5-10 volumes of the nuclei lysis buffer containing 0.5 M EDTA, pH 9-9.3, $1 \%$ sodium lauryl sarcosine, and $0.3 \mathrm{mg} / \mathrm{ml}$ proteinase $\mathrm{K}$ and incubated at $50^{\circ} \mathrm{C}$ for 24 hours with gentle rotation shaking (Zhang et al. 1995). The plugs were then washed once in ice-cold TE (10 mM Tris-HCl, $\mathrm{pH} 8.0,1 \mathrm{mM}$ EDTA, pH 8.0), three times in ice-cold TE plus $0.1 \mathrm{mM}$ phenylmethyl sulfonyl fluoride (PMSF), and three times ice-cold TE, with one hour each wash. The plugs were stored in TE at $4^{\circ} \mathrm{C}$ before use. 


\section{Determination of Optimal Partial Digestion Conditions}

To determine optimal conditions for partial digestion of DNA embedded in the LMP agarose plugs, reactions were set up according to Zhang (2000). Specifically, three $100-\mu 1$ plugs were cut into equal slices, 9 slices/plug, with a glass slide cover and incubated with $8.73 \mathrm{ml}$ of buffer I $\left(7,803 \mu \mathrm{l} \mathrm{H}_{2} \mathrm{O}, 900 \mu \mathrm{l} 10 \mathrm{x}\right.$ enzyme reaction buffer, $18 \mu \mathrm{l} 1 \mathrm{M}$ spermidine, $9 \mu 11 \mathrm{M}$ DTT) on ice for $30 \mathrm{~min}$. The buffer was then drained, replaced with the same volume of fresh Buffer I and incubated on ice for an additional $30 \mathrm{~min}$. The buffer was discarded again, and the gel slices containing rose DNA were transferred into $1.5 \mu 1$ micro-tubes, with three slices per tube and each tube containing $170 \mu \mathrm{l}$ of Buffer II (142 $\mu 1$ $\mathrm{H}_{2} \mathrm{O}, 17 \mu \mathrm{l} 10 \mathrm{x}$ enzyme reaction buffer, $0.34 \mu \mathrm{l} 1 \mathrm{M}$ spermidine, $0.17 \mu \mathrm{l} 1 \mathrm{M}$ DTT, $10 \mu \mathrm{l} 10$ $\mathrm{mg} / \mathrm{ml} \mathrm{BSA).} \mathrm{The} \mathrm{restriction} \mathrm{enzyme} \mathrm{BamHI} \mathrm{was} \mathrm{added} \mathrm{to} \mathrm{each} \mathrm{tube} \mathrm{at} \mathrm{the} \mathrm{following}$ amount of the enzyme: $0.0,0.1,0.25,0.5,0.8,1.0,1.2,2.0$, or 4.0 units. The reactions were incubated on ice for $100 \mathrm{~min}$, and then transferred $\mathrm{d}$ to a $37^{\circ} \mathrm{C}$ water bath and incubated for $8 \mathrm{~min}$. The reactions were stopped by immediately transferring the tubes after the 8-minute incubation onto ice and adding 1/10 volume of $0.5 \mathrm{M}$ EDTA, $\mathrm{pH}$ 8.0.

The partially digested rose DNA in the agarose plug slices were loaded into a $1 \%$ pulsed-field agarose gel in $0.5 \times$ TBE (45 mm Truism base, $45 \mathrm{~mm}$ boric acid, $1 \mathrm{~mm}$ EDTA, $\mathrm{pH} 8.3$ ), and sealed with the agarose used to make the gel. The $\lambda$ DNA ladders were also loaded along with the rose DNA as DNA molecular weight markers. The pulsed-field gel electrophoresis (PFGE) was performed $0.5 \times$ TBE under the following condition: $12.5^{\circ} \mathrm{C}$ (cooler settings), 80 (pump settings), $120^{\circ}$ angle, $6 \mathrm{~V} / \mathrm{cm}$, initial pulse time of 50 seconds, and final pulse time of 50 seconds for $20 \mathrm{~h}$. The gel was then stained with ethidium bromide and photographed. 


\section{Large-scale Partial Digestion of Megabase DNA, Size Selection, Ligation and}

\section{Transformation}

After optimal conditions have been determined, a large-scale partial digestion of 10 100- $\mu$ l plugs was performed using the optimal enzyme concentration determined above according to Zhang (2000) with some modifications. Instead of individual comb wells, a gel was prepared with a single long trough to hold the partially digested DNA plug slices for size selection by PFGE. The PFGE was conducted at $12.5^{\circ} \mathrm{C}$ (cooler settings), 80 (pump settings), $120^{\circ}$ angle, $6 \mathrm{~V} / \mathrm{cm}$, initial pulse time of 90 seconds, and final pulse time of 90 seconds for $14 \mathrm{~h}$, followed by $12.5^{\circ} \mathrm{C}$ (cooler settings), 80 (pump settings), $120^{\circ}$ angle, 4 $\mathrm{V} / \mathrm{cm}$, initial pulse time of 5 seconds, and final pulse time of 5 seconds for $5 \mathrm{~h}$., The partially digested DNA with a size range from $100-400 \mathrm{~kb}$ was collected. As described by Zhang (2000), the DNA marker lane and 2-3 mm of the DNA sample trough were excised, stained, photographed, and re-positioned to the gel to locate the zone of gel ranging from $100-400 \mathrm{~kb}$. The excised gel zone containing the target DNA fragments was divided into three $0.5-\mathrm{cm}$ sections representing fragments ranging from 100-200 kb, 200-300 kb, and 300-400 kb, respectively. These 0.5 -cm thick gel strips were then electroeluted in dialysis tubes (Zhang 2000). The three separate sized fractions were quantified by gel

electrophoresis using $\lambda$ DNA standards of known concentration as the standards, and ligated into the BamHI-digested, dephosphorylated BAC vector pECBAC1 at a molar ratio of 4:1 with an excess amount of vector (Zhang et al. 1996). 


\section{Transformation and Screening of Ligations}

After the ligations for fractions 1,2, and 3 were made, $1 \mu \mathrm{l}$ of each ligation reaction was gently mixed with $20 \mu \mathrm{l}$ of transformation competent E. coli DH10B cells (Invitrogen) and transformed into the competent cells by electroporation using a Life Technology Cell Porator at the settings: $350 \mathrm{~V}, 330 \mathrm{uF}$, low ohms, fast charge rate, and $4 \mathrm{~K}$ ohms. The transformed cells were cultured in $1 \mathrm{ml}$ of SOC medium (Invitrogen) at $200 \mathrm{rpm}, 37^{\circ} \mathrm{C}$ for 1 h. Each fraction ligation culture was plated on the selective agar medium containing $32 \mathrm{~g}$ LB agar, $1 \mathrm{ml} 12.5 \mathrm{mg} / \mathrm{ml}$ chloramphenicol, $75 \mathrm{ul} 200 \mathrm{mg} / \mathrm{ml} \mathrm{IPTG}$ and $3 \mathrm{ml} 20 \mathrm{mg} / \mathrm{ml} \mathrm{X-}$ gal per liter, and grown for a minimum of $24 \mathrm{~h}$ in a $37^{\circ} \mathrm{C}$ incubator for colony color development.

White bacterial colonies presumably containing the rose DNA inserts from each of the three plates (fractions 1, 2, and 3) were analyzed according to Zhang (2000) to estimate the insert sizes of the clones of each ligation. Ten colonies were randomly selected from each of Fractions 1, 2 and 3, respectively and grown at $37^{\circ} \mathrm{C}, 250 \mathrm{RPM}$ overnight, each in 5 $\mathrm{ml}$ of Lure Broth (LB) containing $5 \mu 12.5 \mu \mathrm{g} / \mathrm{ml}$ chloramphenicol (CM). The 30 overnight cultures were then centrifuged for 10 min at 3,200 RPM, and the cell pallet was decanted and re-suspended in the remaining medium (about $0.20 \mathrm{ml}$ ) by Vortexing. Two hundred microliters of Solution 1 (50 mM glucose, $10 \mathrm{mM}$ EDTA, $\mathrm{pH}$ 8.0) was added to each of the 30 cultures and incubated on ice for 5 min After the incubation, $400 \mu$ of freshly made Solution $2[0.2 \mathrm{~N} \mathrm{NaOH}, 1 \%(\mathrm{w} / \mathrm{v}) \mathrm{SDS}]$ was added to each culture and mixed gently by rotating the culture tubes on long axis several times. Three hundred microliters of Solution 3 (3.0 M potassium acetate, $\mathrm{pH} 5.2$ ) was then added to each of the tubes, mixed gently and incubated on ice for 15 - 30 min. To separate the BAC DNA from the bacterial host 
chromosome DNA, the precipitate was centrifuged at $4^{\circ} \mathrm{C}, 3,200$ RPM for $15 \mathrm{~min}$. From each tube, $750 \mu \mathrm{l}$ of the supernatant was transferred into a new $1.5-\mathrm{ml}$ microtube. To the supernatant, $450 \mu \mathrm{l}$ isopropanol was added mixed and centrifuged at room temperature, $12,000 \mathrm{~g}$ for $5 \mathrm{~min}$. The supernatant was discarded, and the DNA pellet was washed in $70 \%$ ethanol, air-dried for about 29 min and re-suspended in TE.

\section{BAC Insert Analysis by PFGE}

$10 \mu \mathrm{l}$ from each of the $40 \mu \mathrm{l}$ DNA isolate solutions was digested with $3 \mathrm{U}$ Not I for 3 hours at $37^{\circ} \mathrm{C}$ in a reaction volume prepared on ice of $40 \mathrm{ul}$ including $23.7 \mu \mathrm{l} \mathrm{H} 2 \mathrm{O}, 4 \mu \mathrm{l} 10 \mathrm{x}$ Not I buffer, $2 \mu 140 \mathrm{mM}$ spermidine. The reactions were stopped by adding 1/10 volume ( $4 \mu \mathrm{l})$ of $10 \mathrm{x}$ loading dye, then heated the at $65^{\circ} \mathrm{C}$ for 10 minute to separate sticky ends, immediately plunged into ice, and run on a $1 \%$ agarose by pulsed-field gel electrophoresis in $0.5 \times$ TBE under the following condition: $12.5^{\circ} \mathrm{C}$ (Cooler settings), 80 (Pump settings), initial pulse time 5 seconds, final pulse time 15 seconds, 120 degree, $6 \mathrm{~V} / \mathrm{cm}$, and 16 hours. The gel was stained for 30 minutes, destained for 30 minutes in water, and photographed under UV light.

\section{Library Assembly}

After selecting the fraction ligation(s) that yielded clones with satisfactory insert sizes, a large-scale transformation was performed on aliquoted vials of $40 \mu$ rose DNA insert/vector into $2 \mu \mathrm{l}$ increments as described above. White colonies were hand picked into 384-well microplates, and incubated overnight at $37^{\circ} \mathrm{C}$ in freezing media as described by Zhang (2000). A total of 80 384-well microplates were assembled for the library. To 
facilitate its long-term storage and screening, the library was duplicated into two copies, with one copy for long-term storage for use of rose genome research and the other one for routine library screening.

\section{High-density Clone Filter Preparation for Library Screening}

High-density clone filters were prepared according to Zhang (2000) by use of the Genomic Solutions GeneTAC G3 Robotic Workstation. Four 384-well microplates were double-spotted onto 7.5 x $11.5 \mathrm{~cm}$ filters (+ an extra copy) in a ' 3 x 3' fashion. superimposed on LB agar medium containing $12.5 \mu \mathrm{l} / \mathrm{ml}$ chloramphenicol and incubated at $37^{\circ} \mathrm{C}$ overnight. Subsequent filter preparation and fixation of BAC DNA to the membranes was according to the procedure described by Zhang (2000).

\section{Primer Design}

To characterize the library and facilitate isolation of the $e v b$ gene, we searched the GenBank for homeologous vernalization and flowering genes cloned to date in other plant species (Zemetra and Morris 1988; Schultz 1991; Mandel et al. 1992; Lee et al. 1994;

Chandler 1996; Dubocovsky et al. 1998; Michaels and Amasino 1999; Johanson et al. 2000;

Kitahara and Matsumoto 2000; Kotoda et al. 2000; Sheldon et al. 2000; Gendall et al. 2001;

Kitahara et al. 2001; Pelaz et al. 2001; Ampomah-Dwamena et al. 2002; Murai et al. 2003;

Yan et al. 2003, 2004; Caicedo et al. 2004; Pillitteri et al 2004). The gene sequences were imported into the PRIMER3 software for primer design (http://frodo.wi.mit.edu/cgibin/primer3/primer3_www.cgi). These sequences before primer design were BLASTed against each other with National Center for Biotechnology Information (NCBI) databases 
(http://www.ncbi.nlm.nih.gov/BLAST/, http://www.ncbi.nlm.nih.gov/blast/bl2seq/bl2.html) by comparing FASTA report common sequences (Tatusova and Madden 1999). Only the unique regions of each gene were used in the primer design for each gene. The primer pairs for each gene were designed using the program "Primer3" with additional criteria to select target sequences greater than $450 \mathrm{~kb}$ for PCR amplification of genomic DNA (Saiki 1990; Zhang 2000). This will maximize the probability of obtaining positive clones from the library using these homeologous sequence probes. 


\section{RESULTS}

\section{Improved HMW DNA Isolation from Roses}

High-molecular-weight (HMW), readily digestible and clonable DNA, is essential for large and complex genome analysis. To facilitate genome research of Rosa species, in particular for construction of large-insert BAC libraries, we previously attempted to isolate HMW DNA from roses according to Zhang et al. (1995) (unpublished). Although DNA fragments $>800 \mathrm{~kb}$ were obtained and readily digestible, they were difficult to be cloned into BAC vectors due to significant contamination with polyphenolic substances, as indicated by the dark brown color of the DNA agarose plugs (Fig. 1A). We also attempted to minimize the phenolic substance contamination by adding polyvinyl pyrrolidone 40 (PVP40) to the DNA extraction buffer of Zhang et al. (1995) as Kaufmann et al. (2003), however, the resultant DNA agarose plugs remained dark brown in color, suggesting that the DNA was not readily clonable. Therefore, we attempted in this study to minimize the polyphenolics by modifying the procedure of Zhang et al. (1995) but not the buffer system (see Materials and Methods).

We particularly made two modifications on the procedure of Zhang et al. (1995).

First, we controlled the rose plant metabolism by maintaining the plants in dark for a few days before tissue collection. This would significantly reduce the phenolic and other metabolic substances that potentially inhibit DNA cloning. Second, we increased wash times of the nuclei from $1-2$ to 6 times before they were embedded into LMP agarose plugs. We modified this step because all of the major metabolic substances, including polyphenolic substances, are synthesized in cytoplasm, and the increased number of 


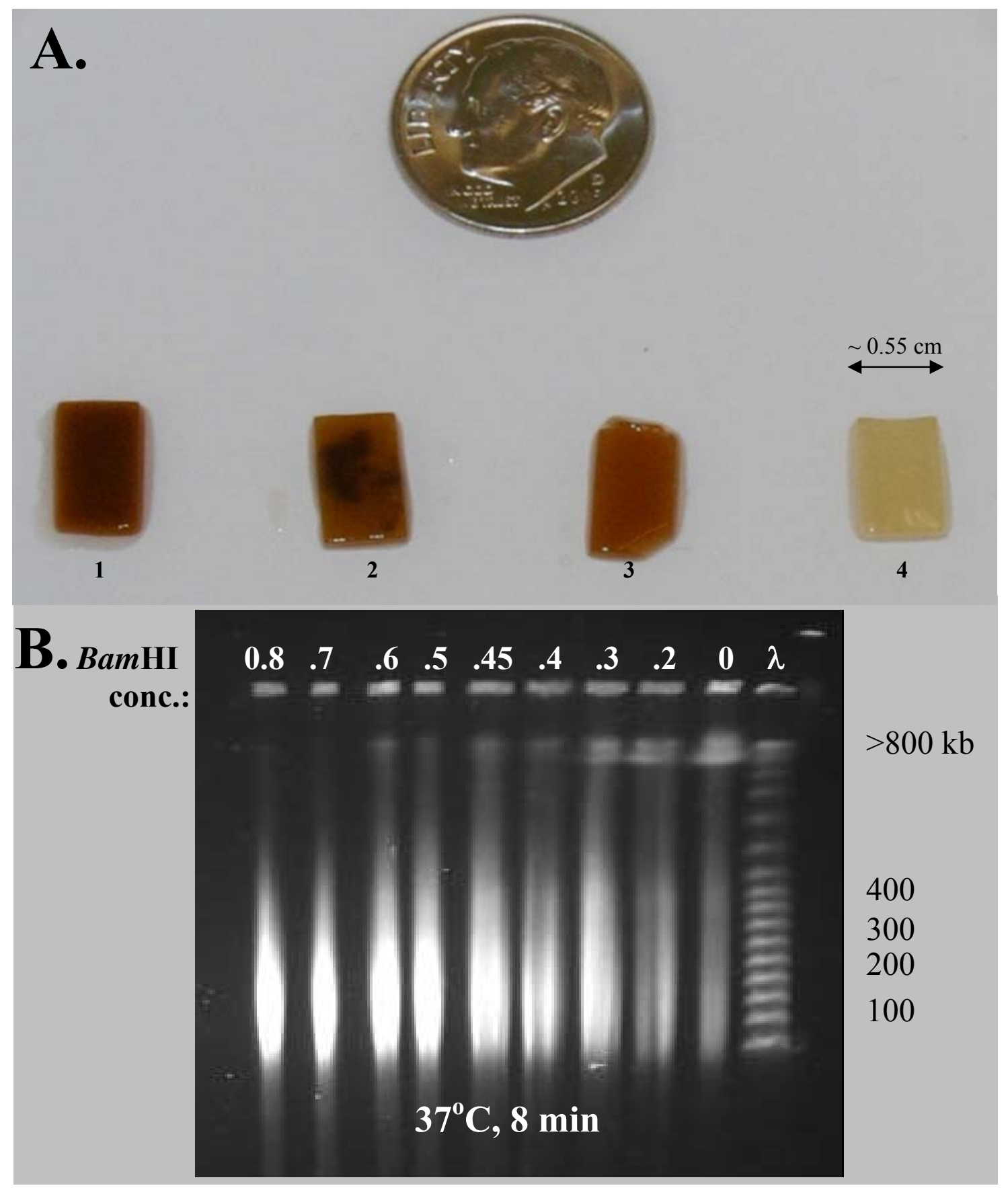

Figure 1. Megabase-sized DNA isolated from rose. A) LMP agarose plugs of the rose DNA isolated with the buffer of Zhang et al. (1995) with (1) and without (2 and 3) PVP40, and the procedure modified in this study (4). Note the differences in phenolics levels indicated by the plug color, with the darkest brown having the most phenolics. B) Rose DNA undigested (0) and partially digested with a series of concentrations of BamHI. 0.6 unites of BamHI (the third lane from left) was selected for large-scale partial digestion and library construction. 
washing and filtrations to the nuclei would minimize the contamination of polyphenolic and other metabolic substances to the nuclei. Figure 1A shows an example of the rose cv. Old Blush DNA LMP agarose plugs isolated with the modified procedure. In comparison with the DNA plugs isolated before, the color of the rose DNA plugs was much lighter even though they were still beige in color. This result suggested that the polyphenolic substance contamination of the plugs had been significantly reduced, thus the clonability of the DNA into $\mathrm{BAC}$ vectors was likely increased.

To test the size, digestibility and clonability of the rose DNA, we digested the DNA with a series of concentrations of $\mathrm{BamHI}$ in a controlled time period $\left(37^{\circ} \mathrm{C}\right.$ for $\left.8 \mathrm{~min}\right)$ and analyzed the digested DNA, along with undigested DNA, on a pulsed-field gel (Fig. 1B). For the undigested DNA, although some of the DNA fragments were observed to be $<400$ $\mathrm{kb}$ in size on the pulsed-field gel that were not suited for large-insert cloning, a majority of the fragments were compressed in the $800-\mathrm{kb}$ compression zone of the pulsed-field gel. This suggested that the DNA isolated with the modified procedure had sufficiently large size for cloning inserts of $150 \mathrm{~kb}$ or larger. For the digested DNA, it was observed that the degree of digestion was markedly increased as the amount of enzyme used increased, suggesting that the DNA was readily digestible for large-insert BAC cloning. Of the varying concentrations of enzyme, 0.6 units of BamHI appeared to produce the greatest amount of restricted fragments arranging between 100 and $300 \mathrm{~kb}$, when compared to the lambda ladder DNA molecular weight standard. Therefore, the concentration of the enzyme was selected for BAC library construction. 


\section{BAC Library Construction}

To answer the question whether the DNA was clonable into BAC vectors and able to construct a BAC library from the rose everblooming cv. Old Blush for positional cloning of the $e v b$ gene, we partially digested the DNA isolated with the modified procedure using 0.6 units of BamHI per reaction under the condition determined above. The DNA was then size selected on a pulsed-field gel and the DNA fragments ranging from 100 to $400 \mathrm{~kb}$ was excised (Fig. 2). To enhance the cloning efficiency of suitable insert sizes, we further subdivided the gel zone containing DNA fragments of $100-400 \mathrm{~kb}$ into three fractions, with expected size of DNA fragments being $100-200 \mathrm{~kb}, 200-300 \mathrm{~kb}$, and $300-400 \mathrm{~kb}$ for fractions 1, 2 and 3, respectively (Fig. 3). The DNA fragments in each fraction were electroeluted, characterized for concentration (Fig. 4), ligated into the BamHI-digested, dephosphorylated pECBAC1 vector (Fig. 5) and transformed into the bacterial host (Table

1). Ten white clones were randomly selected from each ligation and analyzed by PFGE. Fractions 1, 2 and 3 gave 25, 420 and 3 white clones presumed containing rose DNA inserts, respectively (Table 2). The average insert sizes of the clones were shown to be 83,103 and $120 \mathrm{~kb}$ for Fractions 1, 2 and 3. Although Fraction 3 yielded much larger-insert clones than Fractions 1 and 2, but yielding only a few clones per transformation made it difficult to construct a BAC library from such a low transformation efficiency ligation. In comparison, Fraction 2 yielded clones having reasonable average insert size (103 kb) and was also high in transformation efficiency. Therefore, we decided to construct the rose cv. Old Blush BAC library from this fraction ligation. 


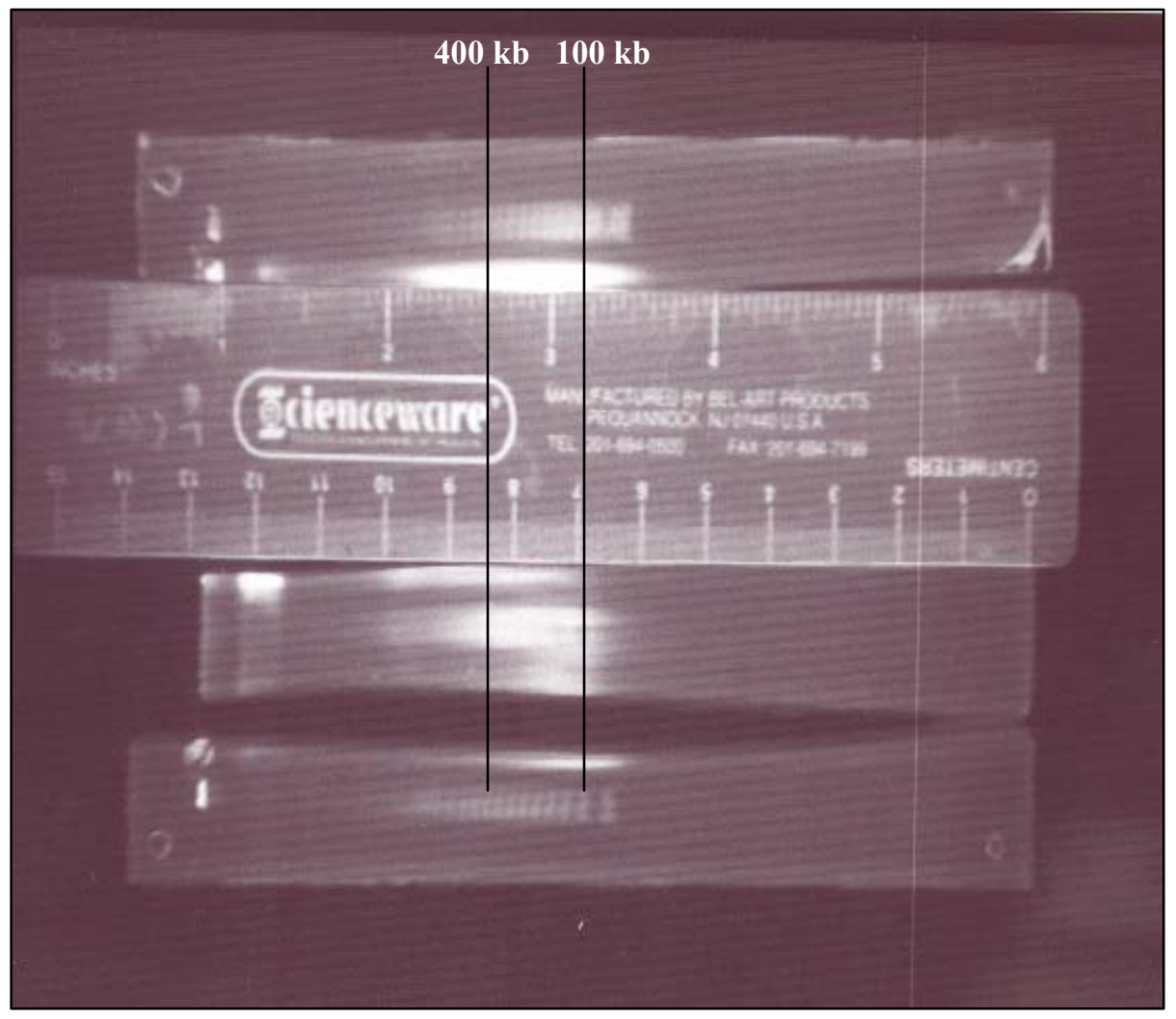

Figure 2. Rose DNA partially digested with BamHI ( 0.6 units, $37^{\circ} \mathrm{C}$ for $8 \mathrm{~min}$ ) and size-selected on a pulsed-field agarose gel. The $100-$ $400 \mathrm{~kb}$ zone was selected for BAC library construction. 


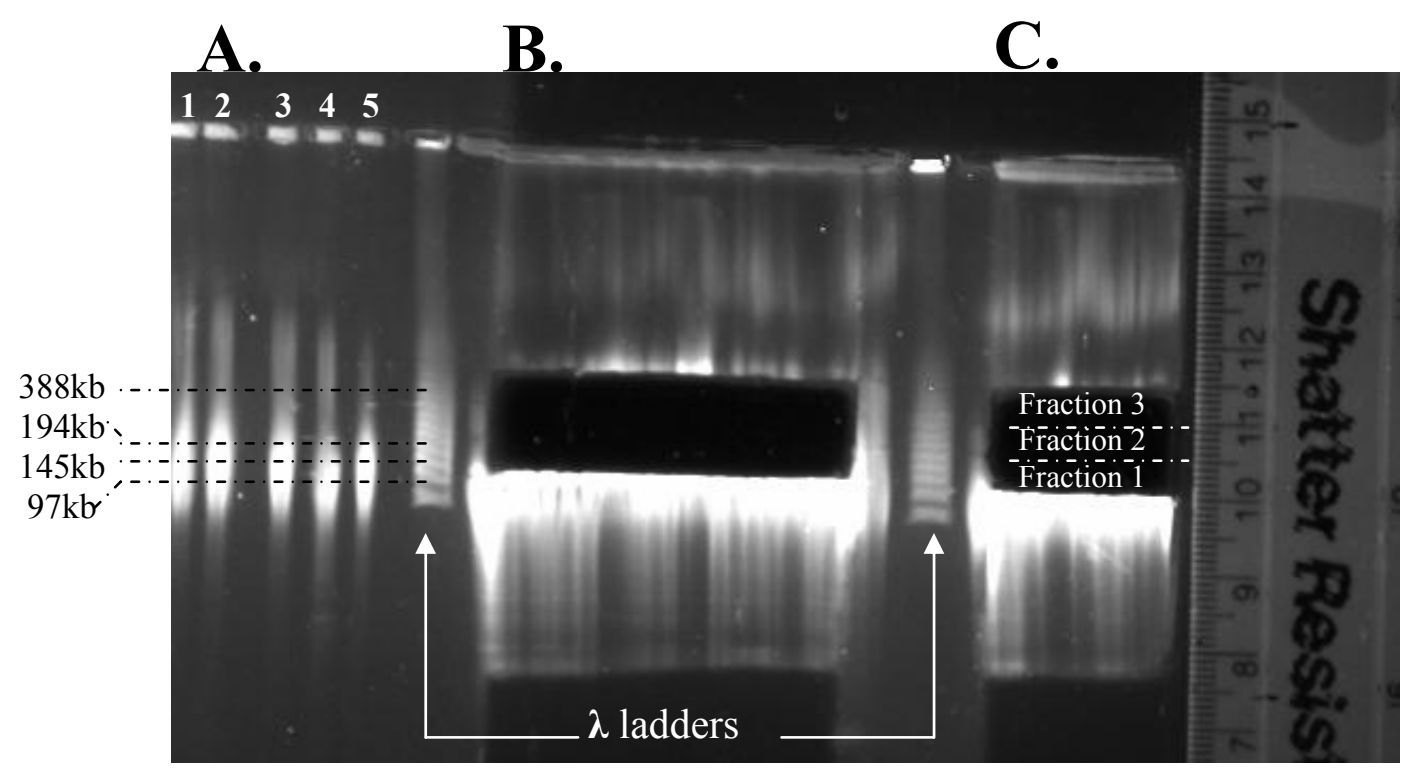

Figure 3. Size selection of BamHI-partially digested fragments on a pulsed-field gel for BAC library construction. A. $3 / 9$ of a $100-\mu 1$ rose DNA plug digested with 0.6 , $0.8,1.0,1.2$, and 2.4 units of BamHI (from lane 1 to 5 ), respectively, at $37^{\circ} \mathrm{C}$ for 8 min. B. Verification of the desirable-size DNA collection. The DNA fragments of 100 - $400 \mathrm{~kb}$ located in Fig. 2 were collected. The figure shows the remaining DNA fragments and verifies the proper collection of the desirable DNA fragments for BAC library construction. C. Factions of the selected DNA zone. Fractions 1, 2, and 3 represent the DNA migrating size of $100-200 \mathrm{~kb}, 200-300 \mathrm{~kb}$, and $300-400 \mathrm{~kb}$, respectively. 


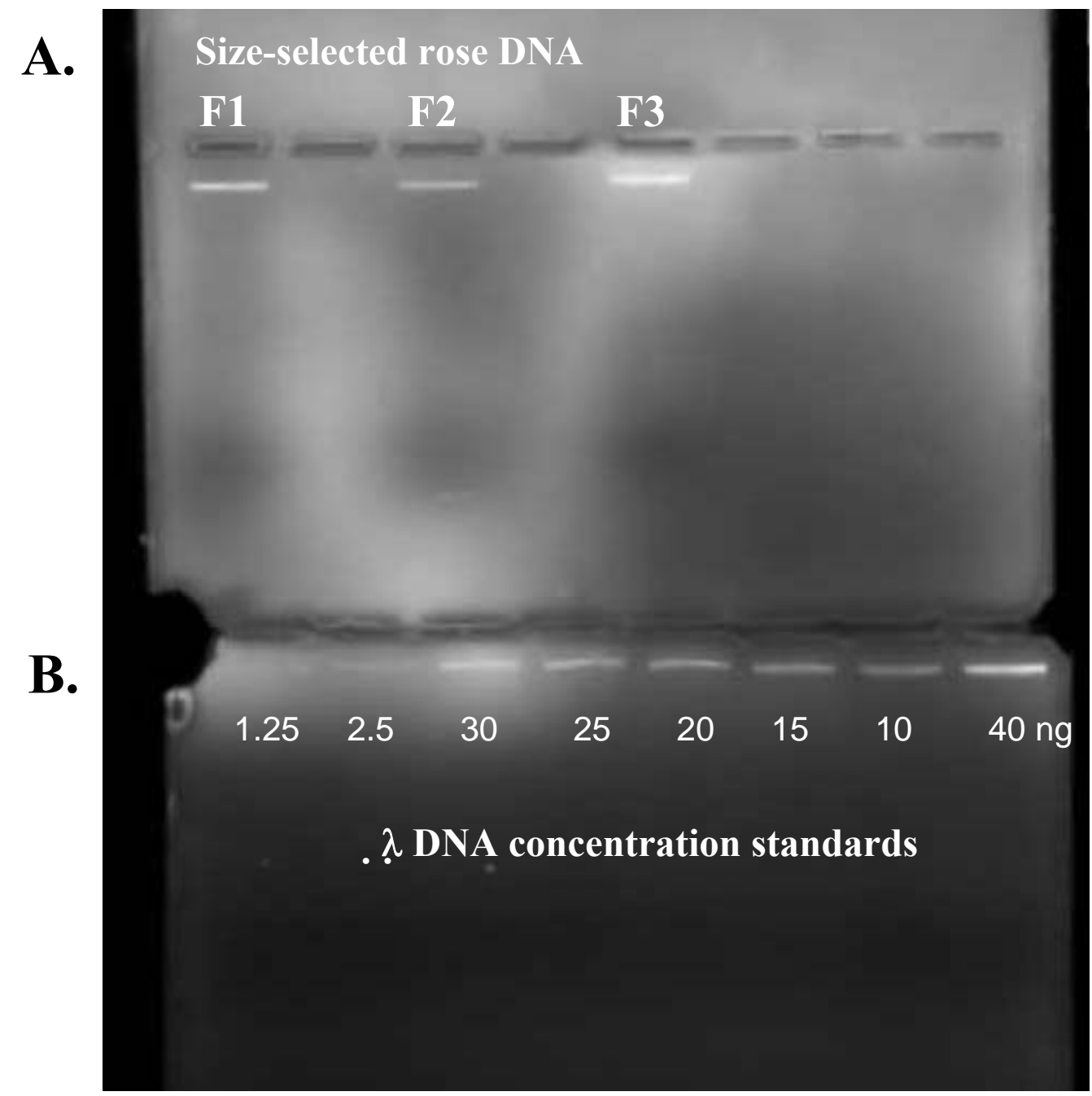

Figure 4. Quantification of DNA fragments resulted from size selection on a $1 \%$ agarose gel. A. $10 \mu \mathrm{l}$ of the DNA electroeluted from each of fractions 1, 2, and 3. B. Lambda standards containing 1.25, 2.5, 30, 25 20, 15, 10, and 40 ng DNA per lane. 


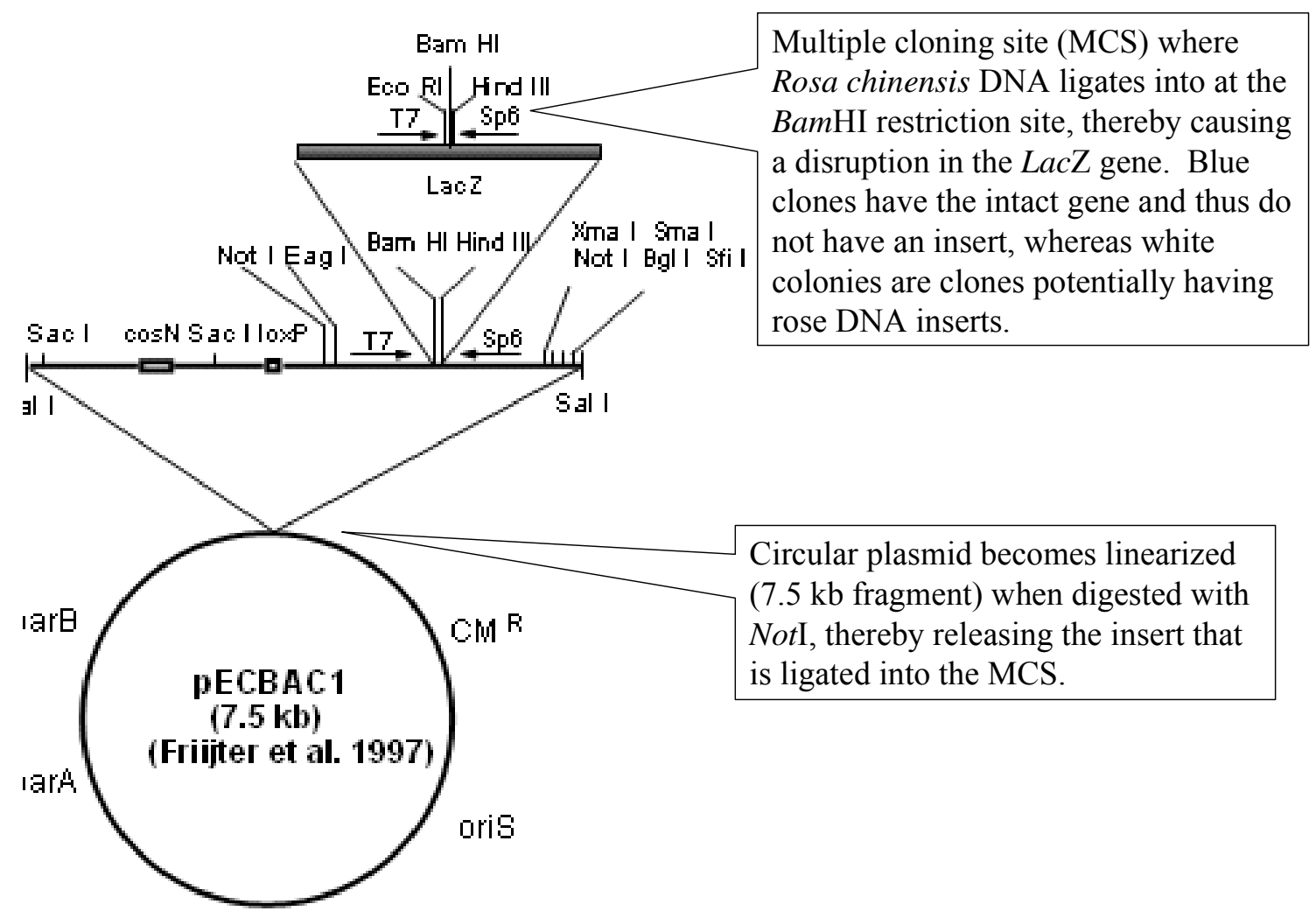

Figure 5. $\mathrm{BAC}$ vector $\mathrm{pECBAC1}$. 
Table 1. Ligation of the three fractions of size-selected DNA fragments into the BamHI-digested, dephosphorylated pECBAC1 vector.

\begin{tabular}{rccc}
\hline & Fraction 1 & Fraction 2 & Fraction 3 \\
\hline $\mathrm{H}_{2} \mathrm{O}$ & $60.3 \mathrm{ul}$ & 0 & 0 \\
R. chinense DNA & $120.0 \mathrm{ul}$ & $390.0 \mathrm{ul}$ & $190.0 \mathrm{ul}$ \\
pECBAC1 vector & $7.2 \mathrm{ul}$ & $7.8 \mathrm{ul}$ & $1.9 \mathrm{ul}$ \\
$5 \mathrm{x}$ buffer & $48.0 \mathrm{ul}$ & $102.0 \mathrm{ul}$ & $50.0 \mathrm{ul}$ \\
T4 DNA Ligase(1u/ul) & $4.5 \mathrm{ul}$ & $10.2 \mathrm{ul}$ & $5.0 \mathrm{ul}$ \\
total volume & $240.0 \mathrm{ul}$ & $510.0 \mathrm{ul}$ & $246.9 \mathrm{ul}$ \\
\hline
\end{tabular}


Table 2. Summary analysis of the clones resulting from three fractions of size selected DNA fragments.

\begin{tabular}{lrrrr}
\hline $\mathrm{N}=10$ & $\begin{array}{l}\text { White } \\
\text { Colonies }\end{array}$ & $\begin{array}{l}\text { Insert size } \\
\text { Ave. (kb) }\end{array}$ & $\begin{array}{l}\text { Blue } \\
\text { Colonies }\end{array}$ & $\begin{array}{c}\text { \% White } \\
\text { (w:b) }\end{array}$ \\
\hline Fraction 1 & 31 & 83 & 155 & 16.7 \\
Fraction 2 & $\mathbf{4 6 9}$ & 104 & 160 & 74.5 \\
Fraction 3 & 05 & 131 & 43 & 10.4 \\
\hline
\end{tabular}


A total of 30,720 clones were individually arrayed into 80 384-microtiter microplates for the rose $\mathrm{cv}$. 'Old Blush' BAC library. To more accurately estimate the average insert fragment lengths of the library, an additional 131 clones were randomly selected and cultured overnight. BAC DNA was isolated, digested with NotI to release the rose DNA inserts from the BAC cloning vector and run on a pulsed field gel (Fig. 6). The insert size of each clone was calculated by adding all bands derived from the rose DNA insert of the clone. The insert sizes of the 140 clones ranged from 40 to $235 \mathrm{~kb}$ with an average insert length of $108 \mathrm{~kb}$, with approximately $50 \%$ of the clones being $>100 \mathrm{~kb}$ (Fig. 7). Less than $3 \%$ of the selected clones had no insert. If $2 \%$ of the clones were assumed to be derived from chloroplasts (Tao et al. 2002; Chang et al. 2003), at least 29,194 clones were derived from the nuclear DNA of rose. Therefore, the library has a conservative estimate of a $5.6 \mathrm{x}$ genome coverage, based on a genome size of $560 \mathrm{Mb} / 1 \mathrm{C}$ for the rose species. The probability of obtaining a positive clone from the library using any single-copy sequence is greater than $99 \%$ and thus the library could be useful for positional cloning of the $e v b$ gene and other rose genome research. To facilitate the long-term maintenance and use of the library, we have duplicated it into two copies, with one of them for long-term storage and the other for library screening. 


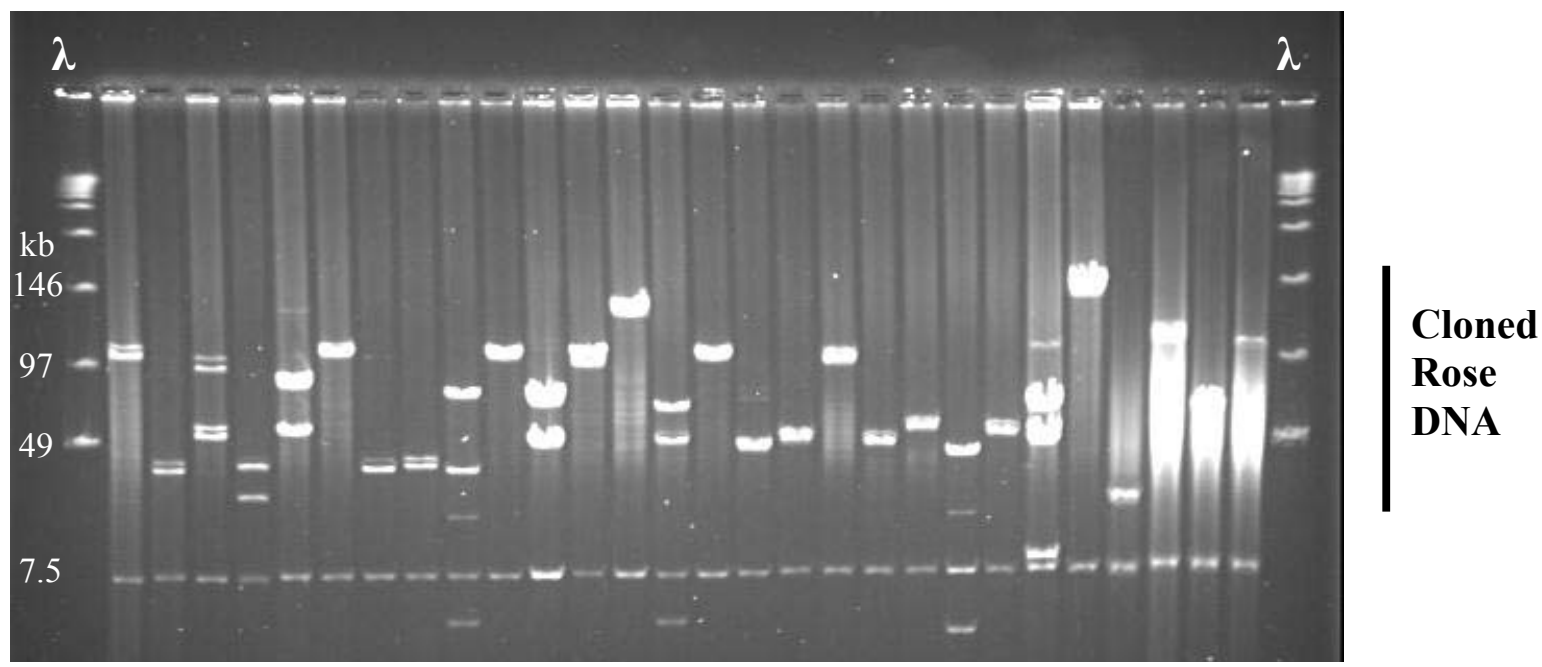

Figure 6. Rosa chinensis BACs digested with Not I and fractioned by PFGE. BAC DNA was isolated, digested with Not I to release the rose DNA inserts from the BAC vector $(7.5 \mathrm{~kb})$ and run on a pulsed-field gel. Lanes 1 and 30 indicate lambda DNA ladder whereas the remaining lanes indicate the BACs randomly selected from the rose cv. Old Brush BAC library. The insert size of each BAC was estimated by summing up the sizes of rose insert bands in the BAC lane. Note that some of bands were derived from multiple fragments that had the same or similar migration rate (or size), as indicated by significantly higher density of the bands relative to their neighboring bands on the same BAC lane. 


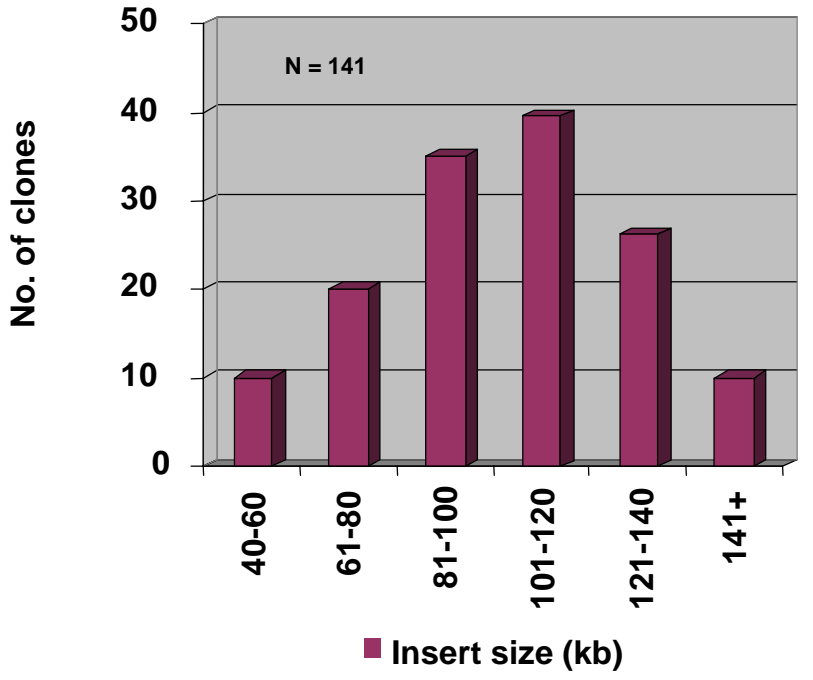

Figure 7. Insert size distribution of the $R$. chinensis $\mathrm{cv}$. Old Blush BAC library. 


\section{Library Filter Preparation and Gene-specific Primer Design for Isolation of the BAC Clones Containing Candidate Genes for Rose Everblooming (evb)}

There are several genes involved in plant flowering cloned from a variety of species including Arabidopsis, Brassica, rose, tomato, and wheat (Zemetra and Morris 1988;

Schultz 1991; Mandel et al. 1992; Lee et al. 1994; Chandler 1996; Dubocovsky et al. 1998; Michaels and Amasino 1999; Johanson et al. 2000; Kitahara and Matsumoto 2000; Kotoda et al. 2000; Sheldon et al. 2000; Gendall et al. 2001; Kitahara et al. 2001; Pelaz et al. 2001; Ampomah-Dwamena et al. 2002; Murai et al. 2003; Yan et al. 2003, 2004; Caicedo et al. 2004; Pillitteri et al 2004). These genes include those controlling vernalization and flower development. These genes are potential candidates for the rose everblooming gene (evb). To determine whether the genes are present at the rose cultivar, what relationship the genes with the evb gene have and further test the utility of the rose BAC library, we made two sets of hybond $\mathrm{N}+$ filters of $7.5 \times 11.5 \mathrm{~cm}$ from the library a ' $3 \times 3$ ' configuration. We also downloaded the DNA sequences of the genes cloned to date controlling vernalization and flower development from Arabidopsis thaliana, Brassica rapa, Lycopersicon esculentum, Triticum monococcum, and Rosa rugosa then designed primer pairs specific for each of the genes (Table 3). The library filters and gene-specific primer pairs have provided essential tools for isolation of the $e v b$ candidate genes from the rose everblooming cultivar Old Blush BAC library. 
Table 3. Designed primers for isolation of homeologous and orthologous genes in rose using the rose cv. Old Blush BAC library.

\begin{tabular}{|c|c|c|c|c|c|c|}
\hline $\begin{array}{l}\text { Source } \\
\text { species }\end{array}$ & Acc. No. & Genes & $\begin{array}{l}\text { Forward (top) and reverse } \\
\text { primers }\left(5^{\prime}-3^{\prime}\right)\end{array}$ & $\mathrm{T}_{\mathrm{m}}$ & $\% \mathrm{GC}$ & $\begin{array}{l}\text { est.PCR } \\
\text { Size(bp) }\end{array}$ \\
\hline \multirow[t]{3}{*}{$\begin{array}{r}\text { Arab. } \\
\text { thaliana }\end{array}$} & AF116527 & $\begin{array}{l}\text { MADS box protein } \\
\text { Flowering locus } \mathrm{F} \\
\text { (FLF) }\end{array}$ & $\begin{array}{l}\text { GTCGCTCTTCTCGTCGTCTC } \\
\text { TACAAACGCTCGCCCTTATC }\end{array}$ & $\begin{array}{l}60.3 \\
59.8\end{array}$ & $\begin{array}{l}60 \\
50\end{array}$ & 570 \\
\hline & AY769360 & $\begin{array}{l}\text { Flowering locus C } \\
\text { protein (FLC) }\end{array}$ & $\begin{array}{l}\text { TACCAACCTCTTTGGTACGG } \\
\text { TTGAAAAGGCCACTGGAAAC }\end{array}$ & $\begin{array}{l}57.6 \\
60.1\end{array}$ & $\begin{array}{l}50 \\
45\end{array}$ & 2007 \\
\hline & AF284501 & $\begin{array}{l}\text { vernalization } 2 \\
\text { protein (VRN2) }\end{array}$ & $\begin{array}{l}\text { AATTTAGGGGAGGCCTCAGA } \\
\text { AAAAGCCGGAGATTTTCCTA }\end{array}$ & $\begin{array}{l}60 \\
58\end{array}$ & $\begin{array}{l}50 \\
40\end{array}$ & 1452 \\
\hline $\begin{array}{l}\text { Brassica } \\
\text { rapa }\end{array}$ & AY356368 & $\begin{array}{l}\text { reduced } \\
\text { vernalization } \\
\text { response 1 (VRN1) }\end{array}$ & $\begin{array}{l}\text { AGGAAAGCTGACAACAACAACA } \\
\text { GGCAAATACATGATGCAACC }\end{array}$ & $\begin{array}{l}59.8 \\
58.9\end{array}$ & $\begin{array}{l}41 \\
45\end{array}$ & 593 \\
\hline $\begin{array}{r}\text { Lyco. } \\
\text { esculentum }\end{array}$ & AY306153 & $\begin{array}{l}\text { SEPALLATA3-like } \\
\text { MADS-box } \\
\text { (LeSEP3) }\end{array}$ & $\begin{array}{l}\text { GGAGAGGTACCAGAAGTGCAA } \\
\text { CTAGGCCCTGCTCCTCCTAC }\end{array}$ & $\begin{array}{l}59.3 \\
60.4\end{array}$ & $\begin{array}{l}52 \\
65\end{array}$ & 492 \\
\hline \multirow[t]{3}{*}{$\begin{array}{l}\text { Triticum } \\
\text { monoc. }\end{array}$} & AY244506 & $\begin{array}{l}\text { MADS-box } \\
\text { transcriptional } \\
\text { factor (AGLG1) }\end{array}$ & $\begin{array}{l}\text { AGATGCAGGTGTGAGGCTTT } \\
\text { TGGCAACTCTCTGTGTGTGA }\end{array}$ & $\begin{array}{l}59.9 \\
59\end{array}$ & $\begin{array}{l}50 \\
50\end{array}$ & 1061 \\
\hline & AY485974 & ZCCT2 (VRN2) & $\begin{array}{l}\text { CCTCGGACCTTTGTGTTAGC } \\
\text { AACCGCATGACATGGACATA }\end{array}$ & $\begin{array}{l}59.7 \\
59.8\end{array}$ & $\begin{array}{l}55 \\
45\end{array}$ & 481 \\
\hline & $\mathrm{AB} 007504$ & $\begin{array}{l}\text { TaMADS\#11 } \\
\text { (WAP1) }\end{array}$ & $\begin{array}{l}\text { CTGAAGGCGAAGGTTGAGAC } \\
\text { TGCTTCTCGACGAGTTCCTT }\end{array}$ & $\begin{array}{l}60 \\
60.1\end{array}$ & $\begin{array}{l}55 \\
50\end{array}$ & 236 \\
\hline \multirow[t]{5}{*}{$\begin{array}{l}\text { Rosa } \\
\text { rugosa }\end{array}$} & AB055966 & MASAKO B3 & $\begin{array}{l}\text { TCAAGCAGAGACTACCAGGAA } \\
\text { CAGTCTAGCTTCCTTAACATAAATAGC }\end{array}$ & $\begin{array}{l}57.7 \\
57.7\end{array}$ & $\begin{array}{l}48 \\
37\end{array}$ & 500 \\
\hline & AB038462 & MASAKO BP & $\begin{array}{l}\text { GCGGATGAAAATCTTGGACA } \\
\text { TGAATCAGTCAGGCACACCT }\end{array}$ & $\begin{array}{l}61 \\
59.3\end{array}$ & $\begin{array}{l}45 \\
50\end{array}$ & 600 \\
\hline & AB025645 & MASAKO C2 & $\begin{array}{l}\text { AGCAAGAAGCTGCCAAACTG } \\
\text { ACCACAAAGCGAAGTTGGTT }\end{array}$ & $\begin{array}{l}60.7 \\
60\end{array}$ & $\begin{array}{l}50 \\
45\end{array}$ & 565 \\
\hline & AB099875 & MASAKO euB3 & $\begin{array}{l}\text { GAGATTCGCTGAACTGCACA } \\
\text { GGAACGTCCAAAGATCAAGG }\end{array}$ & $\begin{array}{l}60.1 \\
59.5\end{array}$ & $\begin{array}{l}50 \\
50\end{array}$ & 566 \\
\hline & AB099876 & MASAKO S1 & $\begin{array}{l}\text { CCCTTGAAAGGTACCAAAAATG } \\
\text { GCTGCAGTCATTTGCTGTGA }\end{array}$ & $\begin{array}{l}59.8 \\
61.2\end{array}$ & $\begin{array}{l}41 \\
50\end{array}$ & 499 \\
\hline
\end{tabular}




\section{DISCUSSION AND SUMMARY}

\section{Procedure of Megabase-sized DNA Preparation for Rose}

We have developed a procedure for isolation of quality megabase-sized DNA from Rosa species. The DNA isolated with the procedure is not only large in size and readily digestible, but also readily clonable into large-insert cloning BAC vectors. Roses are among the species that are extremely abundant in phenolic compounds that bind DNA and inhibit isolation, making the DNA difficult to digest and clone. This is particularly true for largeinsert DNA cloning, as encountered in our previous efforts in the rose species. Therefore, although procedures have been available for isolation of megabase-sized DNA from a variety of plant species (Zhang et al. 1995), it is essential to modify the current DNA isolation procedure or develop a new procedure for isolation of quality megabase-sized DNA from rose species. Zhao et al. (1994) and Kaufmann et al. (2003) attempted to control phenolics with PVP40 for preparation of megabase-sized DNA for cotton and rose, respectively. We also previously used the same chemical in preparation of megabase-sized DNA from cotton and rose (unpublished). The DNA isolated with the chemistry containing PVP40 was more readily digested than those without use of PVP40, but was not readily cloned into large-insert clones. The DNA plugs were dark brown in color, suggesting the existence of a significant amount of phenolics and the limited role of PVP40 in controlling phenolics. Instead of modifying the nuclei isolation buffer, we modified in this study the procedure of Zhang et al. (1995), including controlling the accumulation of phenolics in cytoplasm in vivo and extensively filtering the nuclei washes during nuclei isolation. Both approaches seemed helpful to reduce the phenolics contamination, nevertheless, increasing 
the nuclei wash times is considered to be more efficient. This is because the treatment of plants in darkness was conducted in our previous studies using the buffer of Zhang et al. (1995) with or without PVP40 (unpublished), but the clonability of the resultant DNA was not improved significantly. The much lighter color of the DNA plugs prepared with the modified procedure and the results of DNA analysis and BAC library construction have proven the significant improvement of the DNA quality and feasibility of using the DNA for rose genome analysis and large-insert DNA cloning. The modified procedure of megabasesized DNA isolation developed for rose may be applicable to many other plant species that are abundant in phenolics. These species include many of field crops such as cotton, ornamental plants such as roses, and trees such as pine and poplar. Differing from the chemical method such as use of PVP40 and other chemicals in the nuclei isolation buffer (Zhao et al. 1994; Kaufmann et al. 2003), the procedure reported in this study uses the same chemistry of Zhang et al. (1995) that has been widely used in preparation of megabase-sized DNA from a variety of plants. Simply increasing the nuclei wash times of the method is likely non-species-specific and thus, widely applicable to different species abundant in phenolics, whereas the efficiency of the chemical method on controlling phenolics may vary from species to species.

\section{Large-insert BAC Library for Rose Everblooming Cultivar Old Blush}

The successful development of a megabase-sized DNA isolation procedure for roses has allowed us to construct a BAC library from the DNA of the rose everblooming cultivar Old Blush. The library consists of 30,720 clones arrayed in 80 384-well microplates and has an average insert size of about $108 \mathrm{~kb}$, thus covering 5.9 x rose genomes and providing a 
greater than $99 \%$ probability of obtaining a clone from the library using any single-copy sequence as a probe. This $R$. chinensis library, along with the $R$. rugosa cv. Alba BAC library previously developed that has an average insert size of $103 \mathrm{~kb}$ and $5.2 \mathrm{x}$ genome coverage (Kaufmann et al. 2003), collectively covers $11 \mathrm{x}$ rose haploid genomes, therefore, the combined libraries will provide a comprehensive resource for genomics research of rose species. Moreover, as our library was constructed with BamHI and that of Kaufmann et al. (2003) with HindIII, they are complementary to each other, thus providing a better genome coverage than the library constructed with a single enzyme (Wu et al. 2004; Ren et al. 2005). Finally, the $R$. chinensis library represents a different gene pool of roses from the $R$. rugosa library. Particularly, since the source of the $R$. chinensis library, cv. Old Blush, is everblooming (Semeniuk 1971; DeVries and Dubois 1978,1984), as is one of the parents of our population that is being used to genetically map the gene for everblooming (evb), the library will provide useful resources and tools to clone and characterize the evb gene.

Previous studies used double size selections for large-insert BAC library construction (Tao et al. 2002; Chang et al. 2003). In this study, we also conducted two size selections initially, but significantly smaller insert clones and lower transformation efficiency were obtained (data not shown). Therefore, a single round of size selection was performed to construct the rose cv. Old Blush BAC library. The construction of the rose cv. Old Blush BAC library indicates that one round size selection is sufficient for construction of BAC libraries having an average insert sizes of $100-140 \mathrm{~kb}$ (see Table 1). The smaller insert clones in the library resulted from the smaller fragments trapped in the larger fragments reduced the average insert size of the library, but may not significantly affect its utility for rose genome research. 
The rose everblooming trait is a unique natural mutation in the plant kingdom controlled by a single gene. It not only converted the once blooming of the wild-type rose into recurrent blooming, but also significantly shorted the juvenile stage of plants. Therefore, isolation of the gene will provide essential tools and knowledge to modify the juvenile period and flowering nature in other ornamental and horticultural crops. Because there is no knowledge available about the biochemistry and nucleotide sequence of the $e v b$ gene, the candidate gene and positional cloning approaches have become the methods of choice to clone the $e v b$ gene. Several genes involved in plant flowering have been cloned from several plant species (Zemetra and Morris 1988; Schultz 1991; Mandel et al. 1992; Lee et al. 1994; Chandler 1996; Dubocovsky et al. 1998; Michaels and Amasino 1999; Johanson et al. 2000; Kitahara and Matsumoto 2000; Kotoda et al. 2000; Sheldon et al. 2000; Gendall et al. 2001; Kitahara et al. 2001; Pelaz et al. 2001; Ampomah-Dwamena et al. 2002; Murai et al. 2003; Caicedo et al. 2004; Pillitteri et al. 2004; Yan et al. 2003, 2004). Screening of the rose cv. Old Blush BAC library with the cloned gene sequences will not only facilitate characterization of the genes in roses, but also provide a great opportunity for identification and characterization of the $e v b$ gene due to cross homology of genes among related species. 


\section{REFERENCES}

Ampomah-Dwamena C, Morris BA, Sutherland P, Veit B, Yao J-L (2002) Downregulation of TM29, a tomato SEPALLATA homolog, causes parthenocarpic fruit development and floral reversion. Plant Physiol 130(2): 605-617

Byrne DH, Black W, Ma Y, Pemberton HB (1996) The use of amphlidiploidy in the development of blackspot resistant rose germplasm. Acta Hort 424:269-272

Caicedo AL, Stinchcombe JR, Olsen KM, Schmitt J, Purugganan MD (2004) Epistatic interaction between Arabidopsis FRI and FLC flowering time genes generates a latitudinal cline in a life history trait. Proc Natl Acad Sci USA 101(44):15670-15675

Chandler J, Wilson A, Dean C (1996) Arabidopsis mutants showing an altered response to vernalization. Plant J 10:637-644

Clarke L, Carbon J (1976) A colony bank containing synthetic Col E1 hybrid plasmids representative of the entire E. coli genome. Cell 9:97-99

Condliffe PC, Davey MR, Brian Power JB, Koehorst-van Putten H, Visser PB (2003) An optimized protocol for rose transformation applicable to different cultivars. Acta Hort 612:115-120

Crespel L, Chirollet M, Durel CE, Zhang D, Meynet J, Gudin S (2002) Mapping of qualitative and quantitative phenotypic traits in Rosa using AFLP markers. Theor Appl Genet. 105:1207-1214

Debener T (1999) Genetic analyses of important morphological and physiological charactes in diploid roses. Gartenbauwissenschaft 64:14-20 
Debener T, Mattiesch L (1999) Construction of a genetic linkage map for roses using RAPD and AFLP markers. Theor Appl Genet 99:891-899

Debener T, Von Malek B, Mattiesch L, Kaufmann H (2001) Genetic and molecular analysis of important characteristics in roses. Acta Hort 547:45-49

DeVries DP, Dubois LAM (1978) On the transmission of the yellow flower colour from Rosa foetida to recurrent flowrering Hybrid Tea roses. Euphytica 27:205-210

DeVries DP, Dubois LAM (1984) Inheritance of the recurrent flowering and moss characters in F1 and F2 hybrid tea $x$ R. centifolia-mucosa (Aiton) seringe populations. Gartenbauwissenschaft 49:97-100

DeVries DP, Dubois LAM (1996) Rose Breeding: Past, Present, Prospects. Acta Hort $424: 241-248$

Dubocovsky J, Lijavetzky D, Appendino L, Tranquilli G (1998) Comparative RFLP mapping of Triticum monococcum genes controlling vernalization requirement. Theor Appl Genet 97:968-975

Firoozabady E, Mork Y, Courtney-Gutterson N, Robinson K (1994) Regeneration of transgenic rose (Rosa hybida) plants from embrionic tissue. Nat Biot 12:609-613

Gendall AR, Levy YY, Wilson A, Dean C (2001) The VERNALIZATION 2 gene mediates epigenetic regulation of vernalization in Arabidopsis. Cell 107:525-535

Gould JH, Zhou Y, Padmanabhan V, Magallenes-Cedeno M, Newton RJ (2002) Transformation and regeneration of loblolly pine: shoot apex inoculation with Agrobacterium. Mol Breed. 10:131-141

Gudin S (1998) Improvement of rose varietal creation in the world. In Proceedings of World Conference on Horticultural Research: Session 2, Rome, Italy, pp II.1.2.4:1-7. 
Gudin S (2000) Rose: genetics and breeding. Plant Breed Rev 17:159-189

Johanson U, West J, Lister C, Michaels S, Amasino R, Dean C (2000) Molecular analysis of FRIGIDA, a major determinant of natural variation in Arabidopsis flowering time. Science 290:344-347

Karp A, Seberg O, Buiatti M (1996) Molecular techniques in the assessment of botanical diversity. Ann of Bot 78:143-149

Kaufmann H, Mattiesch L, Lorz H, Debener T (2003) Construction of a BAC library of Rosa rugosa Thunb. and assembly of contig spanning $R d r 1$, a gene that confers resistance to blackspot. Mol Gen Genomics 268:666-674

Kitahara K, Hirai S, Fukui H, Matsumoto S (2001) Rose MADS-box genes 'MASAKO BP and B3' homologous to class B floral identity genes. Plant Sci 161(3):549-557

Kitahara K, Matsumoto S (2000) Rose MADS-box genes 'MASAKO C1 and D1' homologous to class C floral identity genes. Plant Sci 151(2):121-134

Koornneef M, Blankestijn-de Vries H, Hanhart, C, Soppe W, Peeters T (1994) The phenotype of some late-flowering mutants is enhanced by a locus on chromosome 5 that is not effective in the Landsberg erecta wild-type. Plant J 6:911-919

Kotoda N, Wada M, Komori S, Kidou S, Abe K, Masuda T, Soejima J (2000) Expression pattern of homologues of floral meristem identity genes LFY and AP1 during flower development in apple. Hort Sci 125:398-403

Lee I, Michaels SD, Masshardt AS, Amasino RM (1994) The late-flowering phenotype of FRIGIDA and mutations in LUMINI-DEPENDENS is suppressed in the Landsberg erecta strain of Arabidopsis. Plant J 6:903-909 
Linde M, Debener T (2003) Isolation and identification of eight races of powdery mildew of roses (Podosphaera pannosa) (Wallr.:Fr.) de Bary and the genetic analysis of the resistance gene Rpp1. Theor Appl Genet 107:256-262

Ma Y, Byrne DH, Chen J (1997) Amphidiploid induction from diploid rose interspecific hybrids. Hort Sci 32:292-295

Ma Y, Crane CF, Byrne DH (2000) Meiotic behavior in a tetraploid rose and its hybrid progeny. Hort. Sci 35:1127-1131

Malek B, Debener T (1998) Genetic analysis of resistance to blackspot (Diplocarpon rosae) in tetraploid roses. Theor Appl Genet 96:228-231

Mandel MA, Gustafson-Brown C, Savidge B, Yanofsky MF (1992) Molecular characterization of the Arabidopsis floral homeotic gene APETALA1. Nature $360: 273-277$

Michaels SD, Amasino RM (1999) FLOWERING LOCUS C encodes a novel MADS domain protein that acts as a repressor of flowering. Plant Cell 11(5): 949-956

Murai K, Miyamae M, Kato H, Takumi S, Ogihara Y (2003) WAP1, a wheat APETALA1 homolog, plays a central role in the phase transition from vegetative to reproductive growth. Plant Cell Physiol 44: 1255-1265

Nelson JC, Sorrells ME, Van-Deynze AE, Lu YH, Atkinson M, Bernard M, Leroy P, Faris JD, Anderson JA (1995) Molecular mapping of wheat: major genes and rearrangements in homeologous groups 4, 5, and 7. Genetics 141:721-731

Pelaz S, Gustafson-Brown C, Kohalmi SE, Crosby WL, Yanofsky MF (2001) APETALA1 and SEPALLATA3 interact to promote flower development. Plant J 26(4):385-394 
Pillitteri LJ, Lovatt CJ, Walling LL (2004) Isolation and characterization of a

TERMINAL FLOWER homolog and its correlation with juvenility in citrus. Plant Physiol 135(3):1540-1551

Rajapakse S, Byrne DH, Zhang L, Anderson N, Arumuganathan K, Ballard RE (2001)

Two genetic linkage maps of tetraploid roses. Theor Appl Genet 103:575-583

Rout GR, Samantaray S, Mottley J, Das P (1999) Biotechnology of rose: a review of recent progress. Sci Hort 81:201-228

Saiki R (1990) Amplification of Genomic DNA, In: Innis MA (ed). PCR Protocols: A Guide to Methods and Applications. Academic Press, Inc. New York, pp13-20

Schultz EA, Haughn GW (1991) LEAFY, a homeotic gene that regulates inflorescence development in Arabidopsis. Plant Cell 3:771-781

Semeniuk P (1971) Inheritance of recurrent and non-recurrent blooming in "Goldlocks' X R. wichuraiana progeny. J Hered 62:319-320

Shizuya H, Birren B, Kim U-J, Mancino V, Slepak T, Tachiiri Y, Simon M. (1992) Cloning and stable maintenance of 300-kilobase-pair fragments of human DNA in Escherichia coli using F-factor-based vecotr. Proc Natl Acad Sci USA 89:87948797

Sheldon CC, Rouse DT, Finnegan EJ, Peacock WJ, Dennis ES (2000) The molecular basis of vernalization: the central role of Flowering Locus C (FLC). Proc Natl Acad Sci USA 97(7): 3753-3758

Taiz L, Zeiger E (1998) Plant Physiology. $2^{\text {nd }}$ edition, Sinauer Associates, Sunderland, Mass. 
Tao Q, Zhang H-B (1998) Cloning and stable maintenance of DNA fragments over 300kb in Escherichia coli with conventional plasmid-based vectors. Nuc Acids Res 26:4901-4909

Tao Q-Z, Chang Y-L, Wang J, Chen H, Schuering C, Islam-Faridi MN, Wang B, Stelly DM, Zhang H-B (2001) Bacterial artificial chromosome-based physical map of the rice genome constructed by restriction fingerprint analysis. Genetics 158:17111724

Tatusova TA, Madden TL (1999) BLAST 2 sequences, a new tool for comparing protein and nucleotide sequences. FEMS Microbiol Lett 174(2):247-250

Trevaskis B, Bagnall DJ, Ellis MH, Peacock WJ, Dennis ES (2003) MADS box genes control vernalization-induced flowering in cereals. Proc Natl Acad Sci USA 100(22):13099-13104

van der Salm TPM, van der Toorn CGJ, Bouwer R, Hänisch ten Cate CH, Dons HJM (1997) Production of ROL gene transformed plants of Rosa hybrida L. and characterization of their rooting ability. Mol Breed 3(1):39-47

Vinatzer BA, Zhang H-B, Sanasavini S (1998) Construction and characterization of a BAC library of apple (Malus x domestica Borkh.). Theor Appl Genet 97:11831190

Wang B, Wang Q, Qu X, Zhang K, Jin D (2001) Construction and characterization of a bacterial artificial chromosome library of peach. Theor Appl Genet 103:11741179

Yan L, Loukoianov A, Tranquilli G, Helguera M, Fahima T, Dubcovsky J (2003) Positional cloning of the wheat vernalization gene VRN1. Proc Natl Acad Sci 
USA 100(10):6263-6268

Yan L, Loukoianov A, Blechl A, Tranquilli G, Ramakrishna W, SanMiguel P, Bennetzen JL, Echenique V, Dubcovsky J (2004) The weat VRN2 gene is a flowering repressor down-regulated by vernalization. Science 303:1640-1644

Yokoya K, Roberts AV, Mottley J, Lewis R, Brandham PE (2000) Nuclear DNA amounts in roses. Ann. of Bot 85:557-561

Zemetra RS, Morris R (1988) Effects of an intercultivaral chromosomal substitution on winterhardiness and vernalization in wheat. Genetics 119(2):453-456

Zhang H-B, Wing R (1997) Physical mapping of the rice genome with BACs. Plant Mol. Biol. 35:115-127

Zhang H-B, Wu C (2001) BACs as tools for genome sequencing. Plant Phys. Bioch. 39:195-209

Zhang H-B (2000) Construction and manipulation of large-insert bacterial clone libraries manual. Texas A\&M University.

Zhang H-B, Woo S-S, Wing RA (1996) BAC, YAC, and Cosmid Library Construction. In: Foster, G. and Twell, D. (eds.) Plant Gene Isolation: Principles and Practice. John Wiley \& Sons, Ltd. New York, pp. 75-79 Zhang H-B, Zhao XP, Ding D, Paterson AH, Wing RA (1995) Preparation of megabasesized DNA from plant nuclei. Plant J 7:175-184 


\section{VITA}

Name: Gregory Hess

Address: 7117 Ranger Way

Fort Worth, Tx 76133

E-mail: ghess@tamu.edu

\section{EDUCATION}

2005 Master of Science, Plant Breeding, Texas A\&M University, College Station

1997 Bachelor of Science, Biology, University of Texas at Arlington 